\title{
PENGEMBANGAN PEMBELAJARAN PROJECT BASED LEARNING BERMUATAN REFLEKTIF PADA MATA KULIAH PENULISAN KARYA ILMIAH
}

\author{
Nosa Ilvan Gilis \\ Sekolah Tinggi Keguruan dan Ilmu Pendidikan Citra Bakti Ngada-NTT \\ gilisnosa@gmail.com \\ I Ketut Ada Winarta \\ Sekolah Tinggi Keguruan dan Ilmu Pendidikan Citra Bakti Ngada-NTT \\ winartaadaik@gmail.com
}

\begin{abstract}
Abstrak
Penelitian ini didasari atas temuan bahwa mata kuliah penulisan karya ilmiah belum optimal, baik dari sisi konten dan kurang mampu mengembangkan daya nalar mahasiswa yang mampu menghasilkan produk berupa karya tulis. Oleh karena itu, secara spesifik tujuan dari penelitian ini adalah mengembangkan bahan ajar project based learning bermuatan reflektif pada mata kuliah penulisan karya ilmiah. Penelitian ini dikembangkan dengan model ASSURE, dengan melihat aspek konten, bahasa dan desain selanjutnya akan di ujicoba terbatas pada mahasiswa STKIP Citra Bakti. Hasil penelitian menunjukkan aspek konten, desain dan bahasa dengan kategori sangat baik, serta penilaian mahasiswa dengan kategori sangat baik. Oleh karena itu,bahan ajar yang telah dikembangkan siap di implementasikan.
\end{abstract}

Kata Kunci: Project Based Learning, Reflektif, Penulisan Karya Ilmiah

\begin{abstract}
This research is based on the finding that the subject of scientific writing is not optimal, both in terms of content and less able to develop the reasoning power of students who are able to produce products in the form of writing. Therefore, the specific objective of this research is to develop reflective charged project based learning teaching materials in scientific writing subjects. This research was developed with the ASSURE model, by looking at aspects of content, language and design, the trial will be limited to STKIP Citra Bakti students. The results showed aspects of content, design and language with a very good category, and assessment of students with a very good category. Therefore, teaching materials that have been developed are ready to be implemented.
\end{abstract}

Keywords: Project Based Learning, Reflective, Writing Scientific Works

\section{Pendahuluan}

Pendidikan sangat berperan di era globalisasi yang menjadi pengaruh dalam meningkatkan kualitas sumber daya manusia (SDM), melalui pendidikan manusia lebih berusaha meningkatkan potensinya dalam berbagai keterampilan yang dimiliki oleh dirinya maupun dalam berbagai bidang lainnya. Manusia yang berkualitas akan lebih mempertahankan dirinya untuk melawan zaman yang sekarang sangatlah berbeda, zaman yang dimana banyak tantangan. Manusia yang berkualitas akan lebih mempunyai prinsip untuk untuk lebih melawan zaman yang sudah berkembang.

Dengan hal demikian, upaya yang bisa dilakukan untuk menghasilkan SDM yang berkualitas yaitu dengan pendidikan. Pendidikan merupakan hal yang paling pokok bagi manusia, pendidikan sangatlah berperan bagi manusia, karena melalui pendidikan manusia banyak memperoleh pengetahuan, mendapatkan wawasan yang sangat luas dan mengembangkan kemampuan kreativitas yang dimiliki dan mengubah hal-hal baru untuk ke arah yang lebih baik.

Seiring dengan arus perkembangan IPTEK yang begitu pesat perguruan tinggi dituntut untuk meningkatkan mutu lulusan yang berarti tidak hanya mengandalkan izasah tetapi lebih fokus pada keterampilan yang diperoleh mahasiswa. Dalam menghadapi hal tersebut pemerintah mengupayakan pada seluruh PT untuk mengimplementasikan kerangka kualifikasi nasional Indonesia (KKNI). Menurut Perpres No. 8 tahun 2012 KKNI merupakan perwujudan mutu dan jati diri Bangsa Indonesia. Sektor penting KKNI adalah perumusan Capaian Profil lulusan dan Capaian Pembelajaran (CP) yang nantinya diukur dengan pengalaman kerja yang diperoleh mahasiswa yang tertuang dalam bahan ajar sebagai penyukses ketercapaian profil lulusan. Untuk menjawab CPL tersebut, salah satu pendongkraknya melalui mata kuliah penulisan karya ilmiah. 
Mata kuliah penulisan karya ilmiah merupakan salah satu mata kuliah yang wajib ditempuh oleh mahasiswa STKIP Citra Bakti. Mata kuliah ini dapat diprogramkan pada semester genap dan terhitung 2 sks dengan manfaat mahasiswa mampu menjadi guru yang memiliki pengetahuan, ketrampilan di bidang penulisan karya ilmiah sehingga membentuk seorang guru yang professional. Mata kuliah ini merupakan ini secara langsung menjawab salah satu profil lulusan yaitu sebagai peneliti bidang pendidikan dan pembelajaran. Tugas mahasiswa selama ini diarahkan untuk membuat PKM (program Kreativitas Mahasiswa) diharapkan mereka mampu bersaing dalam tingkat nasional.

Tendensi mata kuliah tersebut dengan adanya Menpan Nomor 16 Tahun 2009 tentang angka kredit jabatan dan peraturan bersama Mendiknas dan Kepala Kepegawaian Negara Nomor 3/V/PB/2010 dan Nomor 14 Tahun 2010 tentang petunjuk pelaksanaan jabatan fungsional guru dan angka kreditnya. Dengan diberlakukannya aturan tersebut maka tugas guru ke depan semakin bertambah.

Selama ini, permasalahan terjadi pada perolehan Program Kreatifitas Mahasiswa yang sampai saat ini STKIP Citra Bakti hanya mampu memperoleh pemenangan program tersebut sebanyak 2 judul yaitu pada tahun 2014 dan 2015. Hal ini tentunya tidak sebanding dengan pengajuan proposal yang telah diajukan. Dengan adanya realita tersebut terindikasi bahwa salah satu sektor yang harus dibenahi melalui pengemasan bahan ajar yang tentunya lebih meningkatkan daya berfikir mahasiswa untuk menghasilkan suatu produk. sesuai dengan UU No 12 Tahun 2012 tentang Pendidikan Tinggi. Grellet (1981) berpendapat bahwa bahan ajar membangun kepercayaan dan keyakinan siswa. Florence Martin (2011) dan Prastowo (2011) mengungkapkan para pendesain pembelajaran agar mengembangkan dan mendesain pembelajaran sesuai dengan komunitas lingkungan.

Pengajar yang berkualitas adalah mereka yang paling mampu membantu peserta didik mereka belajar, memiliki penguasaan mendalam terhadap materi pelajaran dan pedagogi (Darling-Hammond 1997). Untuk mencapai hal ini, tidak cukup mengukur apa yang dipelajari peserta didik: penting untuk menargetkan pengalaman kelas yang secara mendasar membentuk pembelajaran peserta didik, dan menekankan berbagai keterampilan yang dibutuhkan untuk kesejahteraan seumur hidup dan kohesi masyarakat Bahan ajar atau materi pembelajaran secara garis besar terdiri dari pengetahuan, keterampilan, dan sikap yang harus dipelajari siswa dalam rangka mencapai standar kompetensi yang telah ditentukan. National Center for Vocational Education Research Ltd/National Center for Competency Based Training memperkuat bahwa bahan ajar adalah segala bentuk bahan yang digunakan untuk membantu guru atau instruktor dalam melaksanakan kegiatan belajar mengajar di kelas. Menurut Depdiknas (2008) Bahan ajar merupakan seperangkat materi yang disusun secara sistematis baik tertulis maupun tidak sehingga tercipta lingkungan atau suasana yang memungkinkan siswa untuk belajar. Sedangkan Hamdani (2013) Bahan ajar adalah seperangkat atau subtansi pembelajaran yang disusun secara sistematis menampilkan sosok utuh dari kompetensi akan dikuasai peserta didik dalam kegiatan pembelajaran. Berdasarkan hal tersebut perlu adanya pengembangan bahan ajar yang sesuai dengan karakteristik mahasiswa sehingga akan meningkatkan daya nalar, pikir serta penciptaan produk sebagai penguat output mahasiswa. Menurut Kristanti (2016) Belajar merupakan hal yang sangat mendasar yang tidak bisa lepas dari kehidupan semua orang.Seiring dengan perkembangan masyarakat dan kebutuhan yang meningkat, pemerintah berupaya untuk meningkatkan kualitas produk dunia pendidikan.Hal yang harus dilakukan oleh dunia pendidikan tentunya harus mempersiapkan sumber daya manusia kreatif, mampu memecahkan persoalanpersoalan yang aktual dalam kehidupan dan mampu menghasilkan teknologi baru yang merupakan perbaikan dari sebelumnya.

Menurut Thomas (dalam Septiyani, 2015) menyatakan bahwa "pembelajaran berbasis proyek merupakan model pembelajaran yang memberikan kesempatan kepada guru untuk mengelola pembelajaran di kelas dengan melibatkan kerja proyek". Pembelajaran berbasis proyek ini lebih berpusat pada siswa dimana dalam pengelolaan pembelajaran di kelas akan dilibatkan suatu kegiatan proyek. Menurut Made (dalam Nikmah, 2016) pembelajaran Project Based Learning merupakan model pembelajaran yang memberikan kesempatan kepada guru untuk mengelola pembelajaran di kelas dengan melibatkan kerja proyek. Kerja proyek memuat tugas-tugas yang kompleks berdasarkan kepada pertanyaan dan permasalahan yang sangat menantang dan menuntut peserta didik untuk merancang, memecahkan masalah, membuat keputusan, melakukan kegiatan investigasi, serta memberikan kesempatan kepada peserta didik untuk bekerja mandiri. Menurut Yulianto (2017) model pembelajaran Project Based Learning pemberian tugas-tugas berdasarkan permasalahan kompleks yang diberikan pada siswa untuk melakukan investigasi permasalahan secara berkelompok. Memberikan kesempatan siswa lebih aktif belajar karena siswa didorong aktif dalam proses bertanya, menginvestigasi, menjelaskan, dan berinteraksi dengan permasalahan. Selanjutnya siswa diminta menghasilkan sebuah produk dari hasil investigasi dan dipresentasikan. Sejalan dengan pendapat sebelumnya, Sumarmi (2012) menyatakan bahwa Project Based Learning adalah proyek perseorangan atau kelompok yang dilaksanakan dalam jangka waktu tertentu guna menghasilkan sebuah produk, kemudian hasilnya ditampilkan atau dipersentasikan. Selain mengerjakan dan menggunakan berbagai macam sumber belajar perlu juga melakukan pendekatan belajar aktif atau berpusat pada siswa. Keuntungan dari model pembelajaran Project Based Learning menurut Moursound, dkk (dalam Sumarmi, 2012) sebagai berikut. Pertama, meningkatkan motivasi. Peserta didik melaporkan bahwa belajar dalam proyek lebih fun dari pada komponen kurikulum yang lain. Laporan-laporan tertulis tentang proyek itu banyak yang 
menyampaikan bahwa peserta didik menjadi lebih tekun sampai kelewat batas. Kedua, meningkatkan kemampuan pemecahan masalah. Penelitian pada pengembangan keterampilan kognitif tingkat tinggi pada peserta didik menekankan perlunya keterlibatan peserta didik didalam tugas-tugas pemecahan masalah dan pembelajaran khususnya bagaimana menemukan dan memecahkan masalah. Ketiga, meningkatkan kolaborasi. Teori-teori kognitif yang baru dan kontrutivistis menegaskan bahwa belajar adalah fenomena sosial, dan peserta didik akan belajar lebih di lingkungan kolaboratif. Pembelajaran Berbasis Proyek merupakan pembelajaran kolaboratif berdasarkan teori konstruksionisme yang diungkapkan oleh Seymour Papert, teori ini menyatakan bahwa pembelajaran akan membentuk pengetahuan dibenak siswa secara bermakna dengan cara melibatkan siswa secara langsung dalam menciptakan suatu produk nyata, atau dengan kata lain pembelajaran diartikan sebagai proses berpikir dengan membuat sesuatu (Learning by making), Warsono (2013). Project-based learning adalah suatu pendekatan pendidikan yang efektif yang berfokus pada kreatifitas berpikir, keterampilan berfikir, pemecahan masalah, dan interaksi antara siswa dengan teman sebaya (sejawat) mereka untuk menciptakan dan menggunakan pengetahuan baru. Rais (2010) menyampaikan Project based learning merupakan sebuah model pembelajaran yang sudah banyak dikembangkan di negara-negara maju seperti Amerika Serikat. Dalam bahasa Indonesia, Project Based Learning (PBL) bermakna sebagai pembelajaran berbasis proyek. Project Based Learning merupakan salah satu strategi pelatihan yang berorientasi pada CTL atau contextual teaching and learning process (Jones, Rasmussen dan Moffit, 1997). Menurut Abidin (2016) Model Pembelajaran Berbasis Proyek (Project Based Learning) adalah model pembelajaran secara langsung melibatkan siswa dalam proses pembelajaran melalui kegiatan penelitian untuk mengerjakan dan menyelesaikan suatu proyek pembelajaran tertentu. Sedangkan menurut (Mahendra: 2016) adalah model pembelajaran yang menggunakan proyek atau kegiatan sebagai media yang melibatkan peserta didik dalam mentransfer pengetahuan dan keterampilan melalui proses penemuan dengan serangkaian pertanyaan yang tersusun dalam tugas atau proyek. Dengan project based learning Siswa tidak hanya didorong untuk menyelesaikan langkahlangkahnya berdasarkan proyek kelas yang terkait dengan kepentingan pribadi mereka dan kebutuhan, tetapi juga untuk mengembangkan kemampuan berpikir kritis dan menggunakan pengetahuan konten (Kapp, 2009; Tamin \& Grant, 2013). Sejalan dengan hal tersebut bahwa pembelajaran berbasis proyek yang di integrasikan dalam pembelajaran bahasa dapat meningkatkan komunikasi komunikatif (Vaca \& Gómez: 2017). Bie (2012), dalam pembelajaran berbasis proyek, siswa akan melalui proses panjang dalam penyelidikan, menanggapi pertanyaan dari masalah yang kompleks, atau tantangan, melatih keterampilan yang dituntut di abad 21. Menelisik lebih dalam tentang PBL Roessingh dan Chambers (2011) mengemukakan bahwa elemen penting dalam desain proyek yaitu, (1) gambaran proyek dengan rasionalisasinya, (2) seperangkat tujuan pembelajaran yang jelas dan konsepkonsep kunci, (3) daftar bahan dan sumber daya, (4) memungkinkan seperangkat tugas, dan (5) kriteria penilaian dan rubrik. Menurut Rais (dalam Laraga, 2016) bahwa terdapat kelebihan dan kekurangan pada pembelajaran berbasis proyek. Adapun kelebihan dari pembelajaran berbasis proyek yaitu: 1) dapat meningkatkan motivasi; 2) meningkatkan kemampuan pemecahan masalah; 3) meningkatkan kolaborasi atau kerja kelompok; dan 4) meningkatkan keterampilan mengelola sumber. Sedangkan kelemahan dari model ini yaitu: 1) kebanyakan permasalahan "dunia nyata" yang tidak terpisahkan dengan masalah kedisplinan, untuk itu disarankan mengajarkan dengan cara melatih dan memfasilitasi peserta didik dalam menghadapi masalah; 2) memerlukan banyak waktu yang harus diselesaikan untuk menyelesaikan masalah; 3) membutuhkan biaya yang cukup banyak; 4) banyak instruktur yang merasa nyaman dengan kelas tradisional, dimana instruktur memegang peran utama di kelas; dan 5) banyak yang harus disediakan.

Dalam menyempurnakan penerapan model pembelajaran berbasis proyek ini akan diberikan muatan reflektif, seorang pendidik reflektif juga diharuskan mampu untuk bersikap kritis (Insuasty, \& Castillo, 2010). Hal tersebut dikarenakan konsep pembelajaran reflektif terdiri dari beberapa proses yang pada umumnya bertujuan menumbuhkan sikap eksplorasi dan penyelidikan sehingga mampu membangkitkan kesadaran peserta didik serta menjadi faktor yang mempengaruhi proses pembelajaran pembelajaran (Redulescu: 2013) senada di sampaikan oleh Joke: (2017); Sakereh \& Yousofi (2018) bahwa siswa yang mengevaluasi dirinya sendiri dalam pembelajaran meningkatkan pemahaman umum mereka. Hal ini senada dengan hasil kajian Rohana dan Yunika (2016) Bahwa calon guru yang diajarkan dengan reflektif lebih baik dari pada yang diajarkan dengan konvensional.

Konsep berfikir reflektif melalui pembelajaran reflektif adalah inti dari PPI (Sirajuddin, 2009) Paradigma Pedagogi Ignatian (PPI) terdiri dari tiga unsur utama yaitu pengalaman (experience), refleksi (reflection), dan aksi (action). Model pembelajaran reflektif diterapkan atas asumsi bahwa pembelajaran sebagai proses membelajarkan peserta didik, termasuk mahasiswa, merupakan metode yang efektif dalam menanamkan pengetahuan, sikap dan keterampilan.

Selanjutnya Boud (1989); Degeng (1998); dan Hovermill (2008) menjelaskan bahwa refleksi sebagai kegiatan intelektual dan afektif dimana individu-individu terlibat dalam upaya mengeksplorasi pengalaman dalam rangka mencapai pemahaman. Sulasmono (2011) memberi batasan reflektif sebagai kegiatan intelektual dan afektif dimana individu-individu terlibat dalam upaya mengeksplorasi pengalaman mereka dalam rangka mencapai pemahaman dan apresiasi-apresiasi baru. 
Konsep Model pembelajaran reflektif dikembangkan berdasarkan konsep Zeichner dan Liston (1996) berkenaan dengan konsep "critical reflection" yang terdiri dari tiga tahap/tingkat reflektif yaitu (1) technical level, refleksi dilakukan pada efisiensi aplikasi pengetahuan dalam bentuk cara atau teknik dalam mencapai tujuan pembelajaran yang telah ditetapkan; (2) contextual level, refleksi dilakukan untuk menemukan keterkaitan antara situasi problematik dengan tindakan yang dilakukan melalui aplikasi teori sesuai dengan konteksnya; (3) critical level, refleksi dilakukan berdasarkan pertimbangan kritis, dan nilai-nilai moral/etis. Dalam penelitian ini akan menggunakan konsep reflektif contextual level agar sesuai dengan output dari penulisan karya ilmiah. Dengan demikian tujuan dari penelitian ini untuk mengetahui tingkat kelayakan bahan ajar mata kuliah penulisan karya ilmiah dengan model project based learning bermuatan reflektif dari aspek konten, bahasa dan desain serta kelayakan bahan ajar pada uji kelompok.

\section{Metode}

Penelitian ini merupakan penelitian pengembangan (R\&D), yang dikembangkan menggunakan model ASSURE. Model ini terdiri atas 6 langkah yakni: (1) Analayze Learner, (2) State Objective, (3) Select Methods Media and Material, (4) Utilize Media and Materials, (5) Require Learner Participation, (6) Evaluate and Revise. Pemilihan model assure ini didasari bahwa model ini dikembangkan berdasarkan orientasi pada kelas. Menurut Heinich, Molenda, Russel, \& Smaldino, (2002). Dalam pengembangan bahan ajar ini, rancangan pengembangan disesuaikan dengan model yang digunakan, adapun rancangan sebagai berikut.

1. Menganalisis kebutuhan belajar siswa dengan melihat karakteristik mahasiswa (Analayze Learner)

2. Menetapkan tujuan pembelajaran sebagai pedoman dan panduan kegiatan siswa (State Objective)

3. Menyusun metode bahan ajar yang sesuai dengan karakteristik peserta didik, dengan membuat bahan ajar baru serta melaksanakan uji ahli dan uji perseorangan pada bahan ajar yang telah dikembangkan.

4. Menggunakan/menerapkan bahan ajar yang telah disusun kepada peserta didik dalam proses pembelajaran (Utilize Media and Materials)

5. Melakukan uji kelompok serta meminta tanggapan tentang bahan ajar yang telah diterapkan (Require Learner Participation)

6. Melakukan evaluasi dengan melihat efektifitas penggunaan bahan ajar yang telah digunakan sekaligus merefleksi hasil dari evaluasi guna meningkatkan kualitas bahan ajar.

Penelitian ini dilakukan STKIP Citra Bakti Kabupaten Ngada-Flores-NTT. Dengan merancang bahan ajar project based learning bermuatan reflektif pada mata kuliah penulisan karya ilmiah. Subyek penelitian ini mahasiswa STKIP Citra Bakti yang menempuh mata kuliah penulisan karya ilmiah.

Data mengenai kualitas bahan ajar dilihat dari aspek desain, bahasa dan konten dianalisis secara deskriptif, untuk mengolah data hasil review ahli desain, bahasa, konten dan uji perseorangan. Teknik analisis data ini dilakukan dengan mengelompokan informasi dari data kualitatif yang berupa masukan, tanggapan, kritik, dan saran perbaikan yang terdapat pada angket. Hasil analisis ini kemudian digunakan untuk merevisi produk yang dikembangkan. Data mengenai uji kelompok dan tanggapan bahan ajar dengan memberikan kuisioner sesuai model assure. Dengan memberikan penilaian skala likert. Data mengenai efektifitas penggunaan bahan ajar dianalisis dengan statistik deskriptif.

\section{Hasil dan Pembahasan}

Penelitian ini melibatkan ahli konten, ahli bahasa serta ahli desain dengan menganalisis 10 aspek penilaian. Hasil penilaian ahli dari aspek konten rata-rata 4.6 dengan kategori sangat baik, aspek desain rata-rata 4.5 dengan kategori sangat baik, aspek bahasa rata-rata 4,5 dengan kategori sangat baik.

Setelah dinyatakan layak melalui ketiga ahli tersebut, akan dilanjutkan pada penilaian mahasiswa tentang bahan ajar yang telah tersusun, dengan hasil sebagai berikut.

Tabel 1. Penilaian Mahasiswa terhadap Bahan Ajar yang Dikembangkan

\begin{tabular}{llcc}
\hline & \multicolumn{1}{c}{ Pernyataan } & Rerata & Kategori \\
\hline 1. & Bagaimana tampilan bahan ajar ini? & 4,4 & Sangat Baik \\
2. & Bagaimana Cakupan (keluasan dan kedalaman) isi /uraian materi & 4,6 & Sangat Baik \\
3. & Bagaimana Keruntutan struktur organisasi/urutan isi materi & 4,6 & Sangat Baik \\
4. & Bagaimana Kejelasan dan kesesuaian bahasa yang digunakan & 4,6 & Sangat Baik \\
5. & Bagaimana Kejelasan Tujuan pembelajaran/kompetensi & 4,5 & Sangat Baik \\
6. & Apakah isi materi dapat memotivasi dalam belajar? & 4,6 & Sangat Baik \\
7. & Bagaimana Kejelasan petunjuk pengerjaan soal latihan/tes & 4,5 & Sangat Baik
\end{tabular}


8. Bagaimana Keseimbangan proporsi soal latihan/tes dengan isi materi

4,4 Sangat Baik

Rerata Keseluruhan

4,5

Sangat Baik

Penilaian bahan ajar yang telah dikembangkan dari ahli konten, desain dan bahasa menunjukkan bahwa bahan ajar yang telah di kemas dengan kategori sangat baik. Ini berarti tingkat kelayakan bahan ajar layak untuk digunakan pada kalangan mahasiswa yang dimaksud lebih mengedepankan ciri berdasarkan produk yang dapat mereka refleksi. Penilaian mahasiswa pun seiring dengan hasil kelayakan para ahli, penilaian mahasiswa menyatakan bahwa bahan ajar yang dikembangkan dengan penilaian atau kategori sangat baik.

Pembelajaran diperguruan tinggi adalah pembelajaran andragogis karena pebelajar (mahasiswa) adalah orang-orang dewasa yang mempunyai pengalaman-pengalaman menarik sebagai bahan diskusi serta mereka pula yang memiliki kemampuan dan kemandirian untuk belajar. Bahan ajar adalah segala bentuk bahan yang digunakan untuk membantu pendidik atau instruktur dalam melaksanakan kegiatan belajar mengajar di kelas. Anina dan Cola (2013) Bahan ajar juga digunakan pendidik untuk melengkapi penjelasan lisan dari konsep atau keterangan sehingga pelajaran bisa menjadi nyata untuk siswa. Oleh sebab itu perlu adanya penciptaan secara bersama dalam mendorong pengembangan bahan ajar dalam suatu pendidikan.

Menurut Esmer et.al (2016) menyatakan bahwa penggunaan bahan ajar yang paling efektif harus berkaitan dengan studi kasus dan diskusi serta menggunakan demonstransi sehingga mampu meningkatkan daya nalar peserta didik. Dengan adanya buku ajar pendidik tidak perlu terlalu banyak menyajikan materi didalam kelas sehingga kesempatan dosen untuk untuk membimbing mahasiswa menjadi lebih banyak, sehingga mahasiswa dapat belajar lebih efektif (Senguin 1990). Hal tersebut sesuai yang di ungkapkan Matthew. C Nwike (2013); Tanyanyiwa, \& Mutambanengwe, (2015) Bahwa peserta didik akan lebih baik belajarnya dengan menggunakan bahan ajar yang dibuat oleh pendidik. Hasil kajian tersebut diperkuat pernyataan Huysken et,al (2019) bahwa perancangan modul berbasis project based learning memiliki efek besar keberhasilan para mahasiswa dengan prinsip inisiatif melalui presentasi hasil proyek dan menunjukkan kinerja serta sikap mahasiswa dalam penguasaan konsep materi tersebut meningkat.

\section{Simpulan}

Kebutuhan akan pengembangan diri mahsiswa akan selaras berkembang sesuai dengan perkembangan zaman, oleh sebab itu selaku pendidik seharusnya mampu menyiapkan kebutuhan para peserta didik melalui pengelolaan kelas yang salah satunya diwujudkan melalui pengembangan bahan ajar. Kebutuhan terhadap pengembangan bahan ajar penulisan karya ilmiah telah sesuai dengan kelayakan dari segi konten, bahasa dan desain serta mampu meningkatkan penalaran mahasiswa untuk berfikir logis dan ilmiah.

Pengembangan bahan ajar perlu dikembangan pada mata kuliah lainnya sesuai dengan kebutuhan karakteristik mahasiswa sehingga mampu menciptakan pembelajaran yang lebih menyenangkan.

\section{Daftar Pustaka}

Abidin, Y. 2016. Desain Sistem Pembelajaran dalam Konteks Kurikulum 2013. Bandung: PT Refika Aditama. Aina dan Kola Jacob. (2013). Instructional Materials and Improvisation in Physics Class: Implications for Teaching and Learning\|, Journal of Research \& Method in Education, Vol. 2 (5): 38-42

Aina dan Kola Jacob. 2013. Instructional Materials and Improvisation in Physics Class: Implications for Teaching and Learning\|, Journal of Research \& Method in Education, Vol. 2 (5): 38-42

Bie. 2012. What Is Project-Based Learning?. (Online), (http:// www. Bie.org), diakses 8 Agustus 2018.

Boud, D., Keogh, R. \& Walker, D. 1989. Promoting Reflection in Learning: a Model, London: Kogan Page.

Darling-Hammond, L. (1997). Doing Matters Most: Investing in Quality Teaching. New York.

Degeng, I.N.S. 1998. Mencari Paradigma Baru. Pemecahan masalah Belajar. Dari Keteraturan Menuju ke Kesemrawutan. Pidato Pengukuhan Pengajar Besar IKIP Malang; Malang: IKIP Malang

Depdiknas. 2008. Panduan Pengembangan Bahan Ajar. Jakarta. Direktorat Jenderal Manajemen Pendidikan Dasar dan Menegah.

Esmer, E., Guven, G., Aydin, O., Ozden, B., Efe, K., Sener, N. 2016. Perceptions of Education Faculty Students on Teaching Methods And Materials. Educational Research and Reviews. Vol. 11(12): 1093-1109

Florence Martin. 2011. Instructional Design And The Importance Of Instructional Alignment. Community College Journal of Research and Practice. 35: 955-972

Grellet, F. 1981. Developing Reading Skills: A practical guide to reading comprehension exercises. London: Cambridge University Press.

Hamdani Hamid. 2013. Pengembangan Sistem Pendidikan Di Indonesia. Bandung: Pustaka Setia. 
Heinich, R., Molenda, M., Russel, J.D \& Smaldino, S.E. 2002. Instructional Media and Technologies for Learning. Edisi 7. Merril Prentice Hall. New Jersey-USA

Hovermill, J., Crites, T. 2008. Integrating Content, Pedagogy, and Reflectiv Practice: Innovative New Distance Learning Courses and Programs for Mathematics Teachers. Online Journal of Distance Learning Administration

Insuasty, E.A. \& Castillo, L.C.Z. 2010. Exploring Reflective Teaching through Informed Journal Keeping and Blog Group Discussion in the Teaching Practicum. PROFILE: Issues in Teachers' Professional Development. Vol 12 (2): 87-105.

Joke H. van Velzen. 2016. Measuring senior high school students' self-induced self-reflective thinking. The Journal Of Educational Research. (0):1-9

Jones, Beau Fly, Rasmussen, Claudette M., \& Moffitt, Mary C. (1997) Real Life Problem Solving: A Collaborative Approach To Interdisciplinary Learning. Washington D.C.: American Psychological Association

Kapp, E. 2009. Improving student teamwork in a collaborative project-based course. College Teaching, Vol 57(3), 139-143.

Kristanti, Yulita Dyah, Subiki, Rif'ati Dina Handayani. 2016. Model Pembelajaran Berbasis Proyek (Project Based Learning Model) pada Pembelajaran Fisika Disma. Jurnal Pembelajaran Fisika, Vol. 5 No. 2, Hal 122 - 128. Tersedia Pada: https://jurnal.unej.ac.id/index.php/JPF/article/download/3958/3086/.

Kuysken, H., Olivey, H., McElmurry, K., Gao, M., Avis, P. 2019. Assessing Collaborative, Project-based Learning Models in Introductory Science Courses. Journal of the Scholarship of Teaching and Learning, Vol 19 (1): 6-28.

Laraga, Nur Rafika. 2016. Penerapan Project Based Learning Pada Materi Larutan Penyangga Untuk Meningkatkan kreativitas Dan Hasil Belajar Siswa Kelas Xi Mia Sma Negeri 1 Kabila. Skripsi. Universitas Negeri Gorontalo. Gorontalo.

Mahendra, I Wayan . 2016."Project-Based Learning Bermuatan Etnomatematika dalam Pembelajar Matematika".Jurnal Pendidikan Indonesia. Vol. 6 (1): 106-114.

Matthew. C Nwike. 2013. Effects of Use of Instructional Materials on Students Cognitive Achievement in Agricultural Science. Journal of Educational and Social Research. Vol 2(5): 103-107

Menpan. 2010. Petunjuk Pelaksanaan Jabatan Fungsional Guru Dan Angka Kreditnya. Jakarta: Menteri Negara Pendayagunaan Aparatur Negara dan Reformasi Birokrasi

Nikmah, Nur Hidayatun. 2016. Penerapan Pembelajaran Berbasis Proyek Dengan Chemoentrepreunirship (Cep) Pada Materi Pokok Sistem Koloid Di Ma Nurul Huda Semarang Untuk Meningkatkan Hasil Belajar Dan Kreativitas Peserta Didik. Skripsi. Universitas Islam Negeri Walisongo Semarang. Semarang.

Peraturan Pemerintah Republik Indonesia. UU No 12 Tahun 2012 tentang Pendidikan Tinggi.

Perpres No 8 Tahun 2012. Kerangka Kualifikasi Nasional Indonesia. Jakarta: Presiden Republik Indonesia

Prastowo, A. 2011. Panduan Kreatif Membuat Bahan Ajar Inovatif. Jogjakarta: Diva Press

Radulescu, C. 2013. Reinventing Reflective Learning Methods in Teacher Education. Procedia - Social and Behavioral Sciences, (78): 11-15.

Rais, M. 2010. Project based learning: inovasi pembelajaran yang berorientasi soft skills. Makalah dalam Seminar Nasional Pendidikan Teknologi dan Kejuruan Fakultas Teknik Universitas Negeri Surabaya 11 Desember 2010.

Roessingh, H. \& Chambers, W. 2011. Project-based learning and pedagogy in teacher preparation: staking out the theoretical Mid-Ground. International Journal of Teaching and Learning in Higher Education, Vol 23 (1).

Rohana dan Yunika Lestaria Ningsih. 2016. Model Pembelajaran Reflektif Untuk Meningkatkan Kemampuan Pemecahan Masalah Matematis Mahasiswa Calon Guru. JPPM. Vol 9(2): 145-157

Sakereh \& Yousofi. 2018. Reflective Thinking, Self- efficacy, Self- esteem and Academic Achievement of Iranian EFL students. International Journal of Educational Psychology. Vol 7 (7): 68-89.

Seguin. R. 1990. The Elaboration of School Textbooks. Methodological Guide. UNESCO.

Septiyani, Putri Yunita. 2015. Penerapan Model Project Based Learning Pada Materi Hidrokarbon Dan Minyak Bumi Untuk Meningkatkan Hasil Belajar Dan Aktivitas Siswa Sma N 14 Semarang. Skripsi. Universitas Negeri Semarang. Semarang.

Sirajuddin. 2009. Model Pembelajaran Reflektif: Suatu Model Belajar Berbasis Pengalaman. Dalam Didaktika Jurnal Kependidikan Vol 4 (2): 189-200

Sulasmono, Bambang. 2011. Reflective Teaching Learning Model. Salatiga: Satya Wacana: Chritian University. Sumarmi. 2012. Model-Model Pembelajaran Geografi. Malang: Aditya Media Publishing.

Tamim, S. R., \& Grant, M. M. 2013. Definitions and uses: Case study of teachers implementing project-based learning. Interdisciplinary Journal of Problem-Based Learning, 7(2). 
Tanyanyiwa, V. I., \& Mutambanengwe, B. 2015. Department Involvement in Instructional Materials Development for ODL Study at the Zimbabwe Open University (ZOU). Journal of Learning for Development, 2(2)

Vaca Torres \& Gómez Rodríguez. 2017. Increasing EFL Learners' Oral Production at a Public School Through Project-Based Learning. PROFILE. Vol 19 (2): 57-71.

Warsono dan Hariyanto. 2013. Pembelajaran Aktif: Teori dan Asesmen. Bandung: PT Remaja Rosdakarya Offset.

Yulianto, Aris, A. Fatchan, I Komang Astina. 2017. Penerapan Model Pembelajaran Project Based Learning Berbasis Lesson Study untuk Menıngkatkan Keaktıfan Belajar Siswa. Jurnal Pendidikan: Teori, Penelitian, dan Pengembangan Volume: 2 Nomor: 3 Hal. 448-453. Tersedia Pada: http://journal.um.ac.id/index.php/jptpp/.

Zeichner, K. \& Liston, P. (1996), Reflective Teaching: An Intro-duction. New Jersey: Lawrence Erlbaum 